\title{
Formal Translation On Indonesian President Speech
}

\author{
Asi Intan Pramitha
}

\begin{abstract}
This research analyzes President Speech Script from "State Address by President of the Republic of Indonesia on the Occasion of the $65^{\text {th }}$ Anniversary of Independence of the Republic Indonesia which contains two languages. The purpose of this research is to discover the language expressions to know which the level of formality used in President Speech in translation of Indonesian into English. The writer analyzes the President speech as the unit of analysis. The method of this research is descriptive qualitative by comparing two text of President Speech, the Source Language (Indonesian) and Target Language (English). It uses the level of formality theory to analyze the language expressions used in translation of Indonesian into English. In this research the writer finds that there are some words, phrases, and sentences which those expressions show the formality. Based on this research, the formality mostly showed from the diction or word order and tone. Also, there are some expressions which are generally used by a President in his Speech. So, the result of translation is formal based on the analysis which has been done.
\end{abstract}

Keywords: formal translation, president speech, anniversary of Indonesian Independence day, and language expression.

\begin{abstract}
Abstraks
Penelitian ini menjelaskan tentang pidato president Indonesia pada kegiatan peringatan hari kemerdekaan bangsa Indonesia yang ke-65 tahun. Penelitian ini bertujuan untuk mengetahui tingkat formalitas penerjemahan ungkapan bahasa yang digunakan oleh president Indonesia dalam menyampaikan pidatonya dalam bahasa Indonesia yang kemudian diterjemahan ke dalam bahasa Inggris. Penelitian ini menggunakan metode kualitatif deskriptif dengan membandingkan dua teks naskah pidato, bahasa Indonesia dan hasil terjemahannya dalam bahasa Inggris. Dalam melakukan penelitian ini, peneliti menggunakan teori formalitas berdasarkan sumber acuan buku teori penerjemahan. Penelitian ini, menympulkan bahwa hasil penerjemahan teks naskah pidato dari bahasa Indonesia ke dalam bahasa Inggris banyak menggunakan ungkapan-ungkapan bahasa formal. Hasil dari penelitian ini diharapkan dapat memberikan kontribusi bagi para pembaca dan pemerhati penerjemahan.

Katakunci: Penerjemahan formal, pidato presiden, peringatan hari kemerdekaan Indonesia, dan ungkapan bahasa.
\end{abstract}




\section{A. INTRODUCTION}

Language is a set of symbols in writing and speech which has a regulation about it. Without language we will difficult to transmit a culture and also without it, culture will become slow on its development. "The language becomes the important key to understand culture and all society."1 Based on the opinion above we can see how a big the effect of language in society and otherwise.

"Language which is various from different speaker also has an important role in a translation work. Translation is an effort to translate a message from one language to others." ${ }^{2}$ In this way, a translator must continual realize that not words but the information which have to be delivered. In other word, a translator must understand fully about the source language, its taste, nuance, and its style of language. Transmitting a culture also must be considered accurately.

In translation work, a translator has to notice what the object that will to translate is. In other word, we must look at the text, what kind of the text is and what the importance is. Those are important for creating a communicative translation. Machali says that the actual words used to define translation are different; the definitions share three common notions:

The term "equivalent" which is used by Catfors, Nida and Pincuck, Mc Guire, however, uses the term 'similar', the term 'textual material' or 'text', which are used by

1 Amin Nurdin, et al., Mengerti Sosiologi: Pengantar untuk Memahami Konsepkonsep Sosiologi (Ciputat: UIN Jakarta Press, 2006), p. 63.

2 Frans Sayogie, Teori dan Praktik Penerjemahan: Bahasa Inggris ke Dalam Bahasa Indonesia (Ciputat: Pustaka Anak Negeri, 2009), p. 7.
Catford and Mc Guire, while Newmark uses the term 'written message' and Nida 'SL message', and the term 'replace (ment)' is used by Catford and Newmark, while Nida uses the term 'reproduc(ing)' for the same concept. $^{3}$ Of these three key terms, two of them are of utmost important: 'textu(al)' and equivalent. The term 'text (ual)', or written (SL) message as Nida and Newmark call it, means that the input for the translation process is 'text', rather than individual sentence. Halliday and Hasan define "a text is a language in use which is best regarded as semantic unit, which is encoded in sentence." "Based on the opinion above "text" which is called as a language in use, a translator may not forget to look how the language is used in its text or about its language style.

Style is how the way to speak which is various and situational. Hartman and Stork say "style is the personal uses an individual makes in speech or writing of the language at his disposal." 5 The choices a speaker or writer makes from among the phonological, grammatical and lexical resources of his language have become the subject of many different approaches in stylistics, and many definitions of style have been proposed. ${ }^{6}$ De Vito also says "style is the way in which a speaker or writer utilizes the resources of his languagethe choice he makes and arrangements or patterns which result." very important for translation work as Nida and Taber say that translation is

3 Rochayah Machali, Redefining Textual Equivalence in Translation (Jakarta: The Translation Center, Faculty of Arts-The University of Indonesia, 1998), p. 2.

${ }^{4}$ Ibid, p. 20.

A. Chaedar Alwasilah, Sosiologi Bahasa (Bandung: Penerbit Angkasa, 1998), p. 51

${ }^{6}$ Ibid. p. 51.

${ }^{7}$ Ibid, p. 52. 
consist in reproducing in the receptor language the closest natural equivalent of the source language message, first in terms of meaning and secondly in terms of style.

From many language styles which are in society, we can see from the situation where the speaker is or from the diction. One of them is a formal language. Formal language is style of language in complete shape; it is used in some formal occasions. ${ }^{8}$ This style is expected to use well and concerned. Language is used in formal style such as mandate of presidency, state news, sermons, some important speech, articles or essay which contains some important subjects, etc. Those use a formal language. Keraf also says that a formal language does not only stress on their diction but also in tone and grammar. But still, the most important element is diction which all of it is taken from selected of standard language.

Formal language actually is part of standard language which is called as Standard English for English society and is called bahasa baku for Indonesian people. Formal styles in England society still such a certificate in education field. If we have a certificate, many of job field are in front of us rather than we have not. Even if we get of the best of formal English, our movement is larger than. For instance, we can consort with people who come from high class, medium class, or intellectuals. Based on Hook, Formal English and Informal English have a different just 5\%. ${ }^{9}$ That difference

\footnotetext{
${ }^{8}$ Gorys Keraf, Diksi dan Gaya Bahasa (Jakarta: Gramedia Pustaka Utama, 2007), p. 117.

9 Widarso Wishnubroto, Bahasa Inggris, Dialek, Ragam, Jargon, Slang, Blends, Clipped words (Yogyakarta: Kanisius, 1989), p. 48.
}

generally related to construction, subjunctive, and choice between pronoun and objective pronoun, diction, and tone. The distinction between formal language and informal also felt from their tone. This tone is verbal are. ${ }^{10}$ Formal language has to elaborate whole ideas which want to say regularly- chronological (orderly).

Formal language is part of Standard Language as the writer says before. It is important to know what Standard Language is and what the characteristic of it is. Standard Language or is called bahasa baku in Indonesian. Standard Language is called variation of language science. Ramlan says "Science Language Variation is not including dialect; it is used in formal situation by some intellectuals to communicate their knowledge."11 In addition, there is opinion who says Standard Language also is called as scientific variation.

\section{B. DISCUSSION}

Translation has defined in many ways by different writers, as Catford says "a translation is the replacement of textual material in one language (SL) by equivalent textual material in another language (TL)."12 Other opinion says that translation is the rendering of a source language text into the target language so as to ensure that the surface meaning of the two will be approximately similar and the structures of the source language will be preserved as closely as possible.

Translation based on The Concise Oxford English Dictionary is the act or

\footnotetext{
${ }^{10}$ Ibid, p. 50.

${ }^{11}$ Sugihastuti, Rona Bahasa dan Sastra Indonesia: Tanggapan Penutur dan Pembacanya (Yogyakarta: Pustaka Pelajar, 2009), p. 134.

${ }^{12}$ Rochayah Machali (1998), op. cit. p.
} 
instance of translating and a written or spoken expression of the meaning of a word, speech, book, etc. in another language. The first sense relates to translation as a process and the second as a product. The first sense focuses on the role of translator in taking an original or source text and turning it into a text in another language (target text). The second sense notice on the concrete translation product. ${ }^{13}$ In translation involves two language, we call as the source language (SL) and target language (TL), the forms of the source language (SL) have to be replaced by the forms of the target language (TL). The replacement is done by way of semantic analysis. What translators aim to hold constant in translation is meaning rather than form as Machali says that translation is an act of recreating meaning, not that of creating meaning.

\section{Level of Formality}

Someone uses the different kind of language for different occasion or situation. For this different situation where we speak, it includes variety of language sometimes called style or registers. $^{14}$ It appropriates to the occasion, the size of the group spoken to, the degree of familiarity within the group, and even the subject discussed. Selecting the proper style for a given occasion and shifting from one to another as the circumstances change are not primarily linguistic decisions, but social ones.

${ }^{13}$ Basil Hatim , et al., Translation: An Advance Resource Book ( New York: Routledge, 2008), p.3.

${ }^{14}$ W. Nelson Francis, The English Language: An Introduction Background For Writing (New York: W.W. Norton \& Company.Inc, 1965), p. 253.
Register according to Bolinger defined "a variety that is not typically identified with any particular speech community but it is tied to the communicative occasion. As the opinion above that registers referred to as style, it also generally conceived in terms of level of formality. " 15 Linguists are in agreement that English has five registers or levels of formality:

\section{Frozen of literature}

As Francis says "this two styles, Formal and Frozen are different from the other because it is not conversational but informative and discursive." 16 For Frozen style what Joos calls it is primarily the style of literature, at least in the broad sense of the word. In this sense, literature can be defined as those samples of language or a segment of it values to the point of wishing to preserve their exact expression as well as their content. Furthermore, once the words have been arranged; they are set or frozen into an unchangeable pattern. Beside literature Gleason adds "it is also used in the stranger's style. He confines it on speech (oratorical)." ${ }^{17}$ No reaction from hearer which made him to change his style.

SL : Hadirin sekalian dimohon duduk selama upacara berlangsung.

TL : Participants should remain seated throughout the ceremony.

\section{Formal of expository discourse}

It is not conversational but informative and discursive. The hearer

${ }^{15}$ Susan Berk Seligson, The Bilingual Courtroom (Chicago: The University of Chicago Press, 1990), p. 169.

${ }^{16}$ W. Nelson Francis (1965), op.cit. p. 258. cit. p.54.
17 A. Chaedar Alwasilah (1998), op. 
is not given the opportunity to intervene, to ask questions, to make comment, or to indicate his lack comprehension. The formal style is thus typically style of responsible public writing.

SL : Semua hadirin dimohon duduk selama upacara berlangsung.

TL : Those taking part should sit during the proceeding.

\section{Consultative}

In this style we open a conversation with a stranger; it is safe for that purpose because it will neither offend him by unsolicited intimacy nor throw him off by undue formality. It is also the appropriate style for a discussion of more or less serious matters by a relatively small group.

SL : Silahkan duduk di kursi Anda.

TL : Would you please stay in your seats.

\section{Casual}

It appropriate to easy conversation among acquaintances and friends, except when the seriousness of the occasion or the subject calls for the consultative. In pronunciation it makes much use of elided and slurred form like gonna for going to and its sentence are often elliptical, even telegraphic, dropping redundant grammatical and semantic features in the interest of the directness and brevity such as Coming tonight? for Are you coming tonight?.

SL : Duduklah.

TL : Don't get up.

\section{Intimate}

Intimate style is used by people who know each other so well and whose relationship is so close that each can predict the other's reactions to a given situation with accuracy a large part of the time. Its grammar is reduced to a minimum; utterances are typically very short. Vocabulary is also much reduced and the words that are used often have special meanings deriving from some shared experience which the world outside the intimate group does not about. Pronunciation may be altered; an intimate pair may use a broad form of regional dialectical pronunciation.

SL : Duduk yang enak ya..

TL : Sit tight. ${ }^{18}$

\section{Functional Tenor}

Register may be more narrowly defined by reference to subject matter (field of discourse), to medium (mode of discourse), or to level of formality (manner of discourse).

\footnotetext{
${ }^{18}$ Ibid, pp. 55-56.
} 


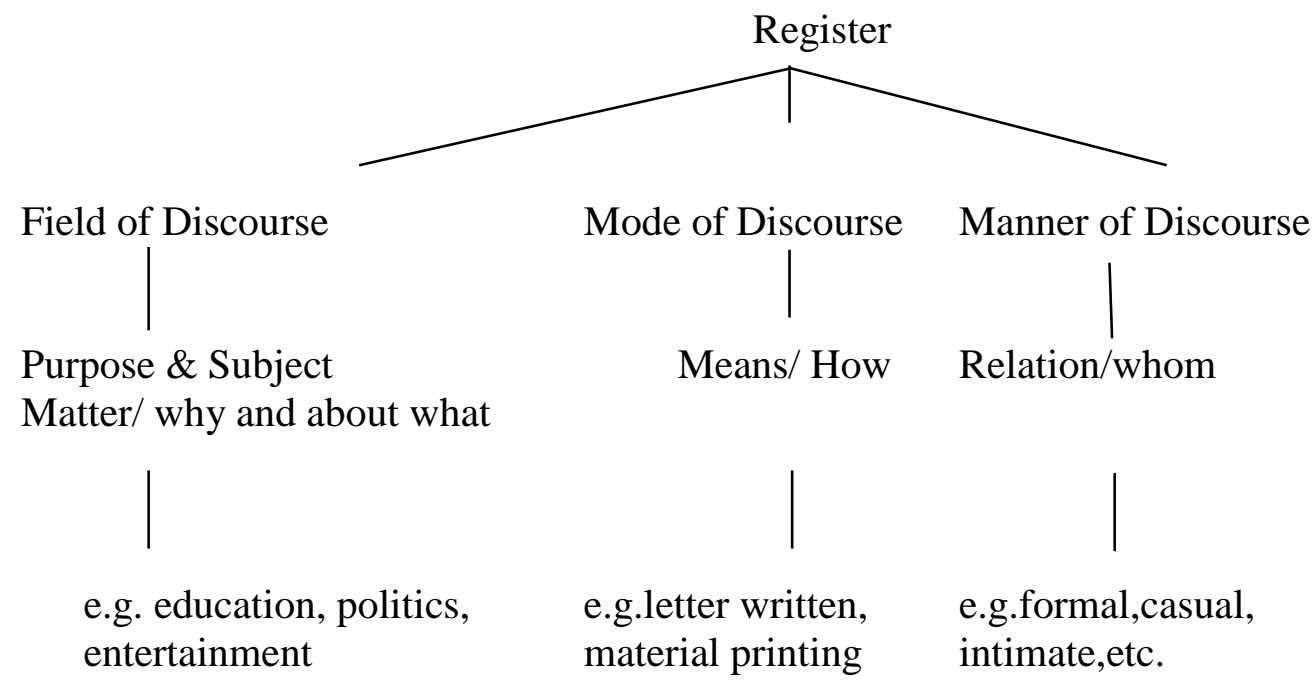

Tenor has to do with the level of formality of the relationship between the participants in the linguistic event. The reason why tenor is a particularly privileged category in register analysis is to do with the overlap between formality and field, on the one hand, and between formality and mode. It is important to note that the crossfertilization taking place between tenor and field tends to give rise to technicality, an important aspect of variation: the more formal the occasion, the more technical the use of language. The overlap between tenor and mode, on the other hand, gives rise to what Gregory and Carroll call "functional tenor". ${ }^{19}$ The category used to describe what language is being used for in the situation. Is the speaker trying to persuade?

\begin{tabular}{|l|}
\hline Technicality/ Formality \\
\hline Field \\
\hline Tenor \\
\hline Mode \\
\hline Functional Tenor \\
Tenor vs. Field and Mode
\end{tabular}

\footnotetext{
${ }^{19}$ Basil Hatim and Jeremy Munday (2008), op., cit. p. 81

${ }^{20}$. Ibid
}

Functional Tenor (to persuade, to discipline, and to inform) thus builds into analysis a set of role relations different in both scope and nature from those identified under the level of formality/ technicality. The participants (e.g. politician vs. electorate, lawmaker vs. public, reporter vs. particular readership) are now defined not only in terms of single- scale categories such as formal or technical, but also in terms of other aspects of interaction.

\section{Translation of Register}

Register mediates between language and situation, we use language registers to access situations. There remains one other important category concerned with language varieties that register. Many texts can be located similarly as regards field, modes, and tenors such as lectures on geography, sermons, cooking recipe book, legal deposition, and sport report. Register is an important sociolinguistic and semantic concept with pertinent relevance to translation. Consistency of register together with what has been referred to as internal cohesion is what makes a text hang together, function as a unit its environment. Moreover Halliday has abstractly described register as the configuration of semantic resources that 
the member of a culture typically associates with a situation type. Thus, the establishment of register equivalence can be seen then as the major factor in the process of translation. $^{21}$

\section{Formal and Informal English}

After we have known about the style based on situation or called registers then we have to learn about their language use, Standard English. Standard English is a language which is the most acceptable language by the most its speaker, England society. It has two varieties which are Formal English and Informal English. Formal English used in formal discourse or speech such as mandate of presidency, state news, sermons, some important speech, articles or essay which contains some important subjects, etc. That's all use a formal language. On the other hand, Informal English sometimes called colloquialism. It is used in daily conversation and more incline relaxed.

According to Hook, Formal English and Informal English have a different is just $5 \% .^{22}$ That difference is generally related to construction, subjunctive, and choice between pronoun and objective pronoun, diction, and tone.

\section{Subjunctive}

In subjunctive, Formal English uses "were" and Informal English uses "was", let's see the example below:

Formal: If she were a queen, she would build her own castle.

If I were you, I would accept her invitation.

Informal: If she was a queen... If I was you, I would...

\section{Diction}

${ }^{21}$ Ibid, p. 191.

${ }^{22}$ Widarso Wishnubroto (1989), op. cit. p. 48.
Sometimes in diction there are difference between Formal English and Informal English so that meaning or the same way is called differently. Let's see some example below:

$\begin{array}{ll}\text { Formal } & \text { Informal } \\ \text { Younger } & \text { kid } \\ \text { (e.g.: younger brother) } & \text { (e.g.: kid brother) } \\ \begin{array}{l}\text { Man } \\ \text { Family }\end{array} & \text { guy } \\ \begin{array}{l}\text { Fine/ very well } \\ \text { All right }\end{array} & \text { folks } \\ \begin{array}{l}\text { Behind } \\ \text { Good bye }\end{array} & \text { okat }(O . K .) \\ \begin{array}{l}\text { Angry / enthusiastic about } \\ \text { (e.g.: He made me angry) }\end{array} & \text { in back of } \\ \text { (e.g.: She is enthusiastic about European cuisine.)(e.g.: She's mad about European } \\ \text { cuisine) }\end{array}$

(e.g.: She's mad about European cuisine) $)^{23}$ 
The distinction between formal language and informal also felt from their tone. This tone is verbal are. ${ }^{24}$ Formal language has to elaborate whole ideas which want to say regularlychronological (orderly). There are three ways which are standardized. They are spelling, verbality, and grammar. Also, there are some ways which have to paid attention.

\section{Spelling}

Spelling meaning can be seen from two aspects, special and common. Specialty, spelling means as a symbol of sounds of language by letter, words, phrases, or sentences. Generally, spelling means whole of regulation about a symbol of sound of language include separation and uniting which also completing with punctuation (Mustakim, 1992). ${ }^{25}$ Next, in a certain language, system of spelling as a rule has three aspects, phonology, syntax, and morphology.

\section{1) Aspect of Phonology}

Principle in phonology aspect, standard language of Indonesia such as process of writing of letter, pronounces, and acronymic. Process of writing in Indonesian is regard about alphabet, vocal, diphthong, consonant, syllable, and proper noun.

2) Aspect of Morphology

Rule of standard language variation which regard the aspect of morphology, are words (affixation, merger, root word, derivative, reduplication, pronoun, preposition, article, particle, and process of writing of number, and some important number, etc.

3) Aspect of Syntax

\footnotetext{
${ }^{24}$ Ibid, p. 50.

25 Sugihastuti (2009), op. cit. p. 141.
}

This aspect includes phrases, clauses, and sentence. In Bahasa, is not known what is called concord or agreement. We say beberapa orang and not beberapa orang- orang because the meaning of plural is enough stated by beberapa. That noun does not need to make to plural.

\section{Language Expression in President Speech}

Language is the expression of people thought. Writing is part of language. More specifically, it is one kind of expression in language - an alternative to sound. ${ }^{26} \mathrm{We}$ have said that a language consist of three strata, they are meaning, wording, and sound. We can now modify this and say that a language consist of meaning, wording, and expression. The expression may take the form either of sound or of writing.

\section{Pretentious Diction}

Words like phenomenon, element, individual (as noun), objective, categorical, effective, virtual, basic, primary, promote, constitute, exhibit, exploit, utilize, eliminate, liquidate, are used to dress up simple statements and give and air of scientific impartially to biased judgments. Adjective such as epoch- making, epic, historic, unforgettable, triumphant, age- old, inevitable, inexorable, veriable, are used to dignify the sordid processes of International politics, while writing that aims at glorifying war usually takes on an archaic color, its characteristic words being: realm, throne, chariot, sword, shield, bucker, banner, jackboot, clarion.

26 M A K Halliday, Spoken and Written Language (Oxford: Oxford Unversity Press, 1989), p. 14. 
Foreign words and expressions such as cul de sac, ancient regime, dues ex machine, mutatis mutandis, status quo, gleichchaltung, weltanschauung, are used to give an air of culture and elegance. Bad writers, and especially scientific, political and sociological writers, are nearly always haunted by the notion that Latin or Greek word are grander than Saxon ones, and unnecessary words such as expedite, ameliorate, predict, extraneous, deracinated, clandestine, subaqueous, etc.

The jargon peculiar to Marxist writing consist largely of words and phrases translated from Russian, German, and France; but the normal way of coining a new word is to use a Latin or Greek root with the appropriate affix and, when necessary, the -ize formation. It is often easier to make up words of this kind (deregionalize, impermissible, extramarital, nonfragmentary and so on) than to think up the English words that will cover one's meaning.

\section{Meaningless Words}

Many political words are similarly abused. The word Facism has now no meaning except in so far it signifies "something not desirable". ${ }^{27}$ The words democracy, freedom, patriotic, realistic, justice, have each of them several different meaning which cannot be reconciled with one another. In the case of a word such democracy, not only is there no agreed definition, but the attempt to make one is resisted from all sides. It is almost universally felt that when we call a country democratic we are praising it: consequently the

\footnotetext{
${ }^{27}$ George Orwell, Language Awareness (New York: ST. Martin Press, 1974), pp. 26-27.
}

defenders of every kind of regime claim that it is a democracy, and fear that they might have to stop using the word if it were tied down to any one meaning. Words of this kind are often used in a consciously dishonest way. Other words used in variable meanings, in most cases more or less dishonestly, are: class, totalitarian, science, progressive, reactionary, bourgeois, equality.

As he voice of George Washington in The Farewell Address, Calvin Coolidge's laconic "I do not choose to run", the language is essentially emotional. As such it will ring changes on the basic compounds of feeling suggested in the following outline; it will consist largely of "good" words and "bad" words. 


\begin{tabular}{|l|l|l|l|}
\hline $\begin{array}{l}\text { Negative } \\
\text { emotions } \\
\text { (threatening) }\end{array}$ & Positive & Emotions & (promising) \\
\hline Disillusionment & Corruption & Hope & Prosperity \\
\hline Distrust & Poverty & Patriotism & Peace \\
\hline Disapproval & Defeat & Love & Security28 \\
& & & \\
\hline
\end{tabular}

$$
\text { * Security }{ }^{28}
$$

Whatever the shade of political opinion, all segments of the public will experience identical hostility or uneasiness on hearing that their country or community is threatened by automation unemployment, riot, cancer, slums, bankruptcy, atomic fallout, another Korea missile attack, gangsterism, sabotage, and depression. As the political voice also knows, the public in general responds warmly to our country, the flag, mother, prosperity, freedom, honor, integrity, brotherhood, justice, friendship, peace, and morality. ${ }^{29}$

\section{Presidential Ethics}

People live in this world together with the others. We help each other to defend our life so we cannot live without other people, it is called social creature. Living in the life among nation and country, people has right and duty which human right comes since the people was born. For remembering we must have respect to others in using our right. We may not bother the other people's right. For the result, we need something which called ethics. Philosopher S. Jack Odell says that a society without ethics is a society towards destruction. ${ }^{30}$ Furthermore,

\footnotetext{
${ }^{28}$ Alexander Scharbach, Critical Reading and Writing (San Fransisco: McGraw- Hill, Inc, 1965), p. 62.

${ }^{29}$ Ibid, pp. 62-63.

30 Richard L. Johannesen, Etika Komunikasi (Bandung: PT Remaja Rosdakarya, 1996), p. 6.
}

ethics is important for a head of state because a president becomes a president for his societies. Whole of a president manner is noticed by a lot of people. In short, a president must keep his attitude in front of public especially. There are some ethics of communication based on Richard L. Johanessen which have to be avoided by a president in his speech as follow:

\section{Using Jargon}

The official governments have to communicate clearly and accurately to their societies in an effort to do their duty as a government. They are not being permitted to use some language which are confused or use jargon to cover the accurateness and presentation of idea which is obvious. Even if those using means to deceive or hide it.

\section{Using Plagiarism}

Plagiarism is something which enough controversial. In fact, not only it happened in education world but also in political event. "Plagiarism" itself comes from Latin for a kidnaper. Someone who steal some words or the ideas from other people without permit is from the sources even he use it as his work, it called plagiarism. One of this case happened in dropping out of Senator of Democrat Party, Joseph Biden from the candidacy of president. Press expresses that Biden in his politic campaign often speech some expression, sentence, and long citations from some speech of John F. Kennedy, Robert Kennedy, and Hubert Humprey without mentions its sources. In The Virtuous 
Journalist, Klaidman and Beauchamp state "citizenships surely hope a good character from the national leaders."

\section{Having Monologist Towards Public}

A president who have a certain attitude such as monologist, he is disfavor with his societies because that attitude shows a superiority. For instance, some speech of President Woodrow Wilson in front of public and press conference, He appear reflects a conviction which is most monologist towards public. In his speech in front of the entrepreneurs in Los Angeles Wilson try to ensure them to support the National League. However, the language of part of his speech expresses his attitude towards the types of people whom he wants to ask for support.

\section{Transformation of Noun and Adjective}

For this case especially in grammar, it happened in Newspeak. Newspeak is a concept of George Orwell showed in 1984, means willfully speak some speech which has double meaning and stale such as by a certain official government. For instance, adjective sometimes built from noun and verb with add suffix "-full", and adverb shaped with increasing suffix "-wise". ${ }^{32}$ Other example is in speech of a state secretary, Alexander Haig. $\mathrm{He}$ transforms noun to verb such as "caveat" and "context". Haig limits a certainty with says "I'll have to caveat my response". And he answers a question by saying he cannot answer it with an expression "in the way you contexted it".

\section{Using Confucius Metaphor}

\footnotetext{
${ }^{31}$ Ibid, p. 13.

${ }^{32}$ Ibid, p. 240.
}

In Orwell's essay "Politics and the English Language" he also says about using mixture metaphor, complex metaphor with confusions or contradiction images. Orwell believes that the mixture metaphor like that is a clear sign that a writer does not see a mental image from the mentioned object. In other word, he does not think fully. ${ }^{33}$ For instance, in a occasion Haig announces "I don't want to burden myself with statistical fence". In the other occasion he says that if a whole of games become implementation of book keeping, we will loose of the definition of a truly destinations. Besides that, in explaining a sprained tongue, he says it due to I think forward and not keeping my feet on the ground.

\section{Over Style}

Still on Orwell, he fulminates an over style. That style often add sentence with an addition syllable, chooses the difficult words and phrases than simple, and also shows a repetition which unnecessary. For instance, in Cancun Conference, the noun which has honestly, "statement", becomes an adjective which is over, "intervention". It is Haig's references to President Reagan in that meeting.

\section{Error Fact}

It happened to President Reagan. There is a accusation that in press conference, informal comment, and sometimes in his Reagan's speech, he fault to state a fact, statistic data, situation, and make a mistake in using description or factual story as his evident. He do it not only in rare occasion but also in surprised frequency, almost routine. One of example of the error fact by Reagan is in a speech early October 1982 in

\footnotetext{
${ }^{33} \mathrm{Ibid}$, p. 241.
} 
veteran meeting at Ohio. Reagan asserts without evident that a movement of stop the latest nuclear weapon is manipulated by people who wanted America becomes weak. ${ }^{34}$ Later the President recognizes that no Americans in his mind as subversive. A leader of Senate Majority, Howard Baker forgives that Presidents statement. Baker says the statement without evident as "a big wipe out comment in campaign time". But article Chicago Tribune panes that Reagan's accusation as wrong and calumniate.

\section{Using Error Anecdote}

Still on Reagan's speech about some fact is a mistake in using illustration and factual story as an evident is done by Reagan. This habit has passed off in long time; it marked as a problem of "anecdotage". He likes to use a real story which lived and dramatic to prove some ways. Unhappily, those anecdotes even if they are not wrong to be mentioned, often mislead and unrepresentative.

\section{Ambiguity and Vagueness}

Some text book of written and spoken communication specifically warns about the ambiguity and vagueness. Those books often directly or indirectly say the ambiguity which is intentionally is a tactic of communication which is not ethic. Most people will be agreeing it is not ethic in situation when the accurate instruction or delivery which is efficient from the correct information is its destination. ${ }^{35}$ Furthermore, in most situation of persuasive communication, ambiguity will be suspected based on ethics. From the State Speech of Republic of Indonesia Transcript. Firstly, she writes

\footnotetext{
${ }^{34}$ Ibid, p. 251.

${ }^{35} \mathrm{Ibid}$, p. 259.
}

the source language text (SL) and the target language text (TL) and then explains the data which is some expressions used in president speech. It must be related to the level of formality in its analysis.

SL: Arti kemerdekaan kita di Abad ke21 , juga mempunyai dimensi yang lebih luas dan kompleks. Dulu, seringkali orang berbicara mengenai "kemerdekaan sebagai bentuk perlawanan terhadap kemiskinan, kebodohan, dan keterbelakangan". Semua itu masih tetap penting dan relevan, dan merupakan bagian dari agenda besar kita. Namun, kini, bangsa kita juga berjuang demi kemerdekaan yang membebaskan kita dari korupsi, dari diskriminasi, dari tindakan anarkis, dan dari ekstremisme serta terorisme.

TL: The significance of our independence during the 21st Century also has a wider and complex dimension. In the past, people used to talk about "independence as a form of struggle against poverty, ignorance, and backwardness". All of this remains important and relevant to, and becomes part of our big agenda. Today, however, our nation is also struggling for independence that liberates us from corruption, from discrimination, from anarchist act and from extremism and terrorism.

We can see that the target language (TL) uses the selected word for its diction "liberate". We can notice it from the root word "liberty" which comes from Greek language means freedom. This diction also used in some text of rhetoric because relate to the nation and country problems. On the other hand, from both the source language and target language can be seen ineffectiveness in syntax 
signed by using some preposition "from" still in same sentence.

Then, from the expressions, we see many bad words in politic who called as threatening such as corruption, discrimination, anarchist, and terrorism. Those words make a foment feeling of anxiety and fear for the public.

SL: Saudara- saudara dan hadirin sekalian yang saya muliakan, Alhamdulillah, setelah 65 tahun merdeka, setelah tiga peralihan generasi, dan setelah mengalami berbagai gejolak dan pasang surut, bangsa Indonesia memasuki Abad ke21 dalam kondisi yang lebih kokoh. Selama tahun 1998 sampai dengan 2008, bangsa Indonesia telah melalui proses reformasi Gelombang pertama dengan selamat, meskipun sarat dengan tantangan dan persoalan yang berat.

TL: Distinguished Ladies and Gentlemen, Thank be God, Alhamdulillah, after 65 years of independence, after three generation changes an after passing through various upheavals and ups- and- downs, the Indonesian nation enters the 21st Century in a stronger condition. During 1998 until 2008, the Indonesian nation has safely passed through the process of the First Wave of Reform, albeit filled with hard challenge and problems.

It is interesting to see the TL as the equivalent for the translation in English. For instance, the word "pasang surut" is translated becomes " ups and downs". The phrase "pasang surut" used to explain the condition of the sea water when the water sometimes go up and go down. In addition, we find the diction to translate "meskipun" becomes "albeit". In generally, we can translate it with "although", that diction shows its formality.
SL: Dalam sepuluh tahun pertama reformasi itu, kita telah melangkah jauh dalam melakukan transisi demokrasi. Kita telah membongkar dan membangun; kita telah melakukan dekonstruksi dan rekonstruksi terhadap tatanan dasar dalam kehidupan politik, sosial, hukum, dan ekonomi. Kita telah melakukan tiga pemilu yang jujur dan adil. Kita mempunyai badan legislative yang sangat independen. Kita telah menciptakan system check and balance yang sehat antar lembaga legislative, eksekutif, dan yudikatif. TNI kembali menjadi tentara profesional, tidak lagi berpolitik, dan berbisnis. Kebebasan pers dan kebebasan berpendapat kini terjamin. Undang- Undang yang diskriminatif telah dihapuskan.

TL: During this first ten years of reformasi, we have advanced far in the transition towards democracy. We have dismantled and built; we have deconstructed and reconstructed the basic order of political, social, legal, and economic spheres. We have conducted three fair and impartial general elections. We have established a sound check and balances system between the legislative, executive, and judicial institutions. The TNI (Indonesia's National Army) resumes as professional soldiers, no longer involved in politics and business. Freedom of the press and of expression is now guaranteed. Discriminative laws have been abolished.

We see the diction in the SL "melangkah" is translated becomes "advanced". Actually, the word "melangkah" in the SL just says steps but the TL directly chooses "advanced" for the equivalent, it assumes step which has meaning to the advance. It explains us that the diction appears the seriousness and what the formal it is. 
Also, if we notice the equivalent of the word "hukum", it translated becomes "legal". The word "legal" itself means allowed or required by law. I think to mention the word "legal", we have to consider to the law first. Besides that, we find the borrowing word which translated faithfully in English; they are "deconstructed and reconstructed". Those root word occurs adding suffix "de" and "-re". It is frequently happened in political act especially for speech. In addition, we can see the diction "dihapus" is translated becomes "abolished". As a result, we see the formality from using that diction, if we generally use "remove or delete" for translate "hapus" in SL.

SL: Dalam periode itu, kita juga telah ,melaksanakan proses desentralisasi yang sangat ekstensif. Kita juga menyelenggarakan pemilihan kepala daerah secara langsung di seluruh Indonesia. Kini, seluruh Gubernur, Bupati, Walikota di Indonesia telah dipilih langsung oleh rakyat. Hasilnya, peta politik Indonesia telah berubah secara fundamental. Pelaksanaan demokrasi langsung ini mengubah banyak hal. Kini,rakyatlah yang berdaulat, bukan lagi sekelompok orang yang mengatasnamakan rakyat.

TL: During that period, we have also carried out a very extensive decentralization process. We have also held direct elections of heads of region all over Indonesia. Today, all Governors, Regents and Mayors in Indonesia are elected directly by the people. As a result, Indonesia's political spectrum has changed fundamentally. This direct democratic practice has changed a lot of things. Today, it is precisely the people who are sovereign, no longer can a group of individuals claim to be the people's representatives.
From the text we see some political words such as election, head of region, Regents, Mayor, Governor, democratic, and sovereign. Even, it also tells about the political spectrum which clearly explains about the political act. Also, we can see the equivalents for the translation some terms of institution such as "Governor" for "Gubernur", "Regent" for " Walikota", and " Mayors" for "Bupati".

SL: Dalam sepuluh tahun pertama, kita juga telah menyelesaikan konflik di Aceh dan melakukan reformasi politik di Papua. Pemerintah dengan seksama terus mempelajari dinamika yang ada di Papua, dan akan terus menjalin komunikasi yang konstruktif dalam pembangunan Papua yang lebih baik. Kita juga terus membangun perdamaian yang berkelanjutan di daerah- daerah pasca- konflik.

TL: During the first ten years, we have also resolved the conflicts in Aceh and conducted a political reform in Papua. The government continues to cautiously observe the prevailing dynamics in Papua, and shall continue to establish constructive communication in the development of a better Papua. We have also been pursuing sustainable peace in post- conflict areas.

We can see the diction in SL "dengan seksama" is translated becomes "cautiously". The phrase "dengan seksama" means accurately, carefully. But, the equivalent which chosen is "cautiously", its diction shows the formality. Besides, we see the other diction "mempelajari" is translated becomes "observe". The diction gives a serious tone which means not only to study but also have to concern continuously. 
SL: Kita telah mendongkrak pertumbuhan ekonomi dari minus 13 persen di tahun 1998 menjadi 6 persen di tahun 2008. Dalam proses yang terus berkembang ini, ekspor non- migas Indonesia menembus US\$ 100 milyar; APBN menembus 1000 triliyun rupiah; cadangan devisa Indonesia kini mencapai lebih dari US\$ 78 milyar; rupiah terus stabil; angka kemiskinan terus menurun; credit rating Indonesia terus membaik; dan rasio hutang atas PDB turun secara signifikan, kini mencapai 27,8 persen, salah satu yang terendah dalam sejarah Indonesia. Dan, yang paling penting, bangsa Indonesia memiliki ketahanan pangan yang semakin kuat.

TL: We have jacked- up the economic growth from minus 13 percent in 1998 to 6 percent in 2008. During this ongoing process, Indonesia's non- oil and gas export surpassed US\$ 100 billion; the State Budget reached over 1000 trillion rupiah; Indonesia's current foreign exchange reserves stand today at US\$ 78 billion; the rupiah continues to decline; Indonesia's credit rating continues to improve; and the debt ratio to GDP has dropped significantly, reaching now 27.8 percent, one of the lowest in Indonesia's history. Furthermore, and most importantly, Indonesia has increasingly strong food resilience.

We can see an equivalent for the institution term here, "APBN" is translated becomes "the state budget". It is not translated to the acronym as the SL did. On the other hand, the acronym in SL "PDB" translated to "GDP". There is the parallelism for that version because we see the sameness shape in SL and TL. Also, we can see the economic term, "cadangan devisa
Indonesia" translated becomes "Indonesia's current foreign exchange reserves". If we see in SL, it use a term "devisa" is translated becomes "foreign exchange", that TL is not a term as the SL.

SL: Kita juga terus giat melaksanakan amanah rakyat untuk memberantas korupsi Program anti- korupsi kita lakukan secara sistemik, berkesinambungan, mulai dari atas (topdown), dan tanpa pandang bulu. Sebagaimana yang terjadi di NegaraNegara lain, perjuangan anti korupsi di negeri ini akan terus menghadapi tantangan dan resistensi. Namun, kita tidak akan patah semangat; kita akan terus berikhtiar, karena kita semua ingin melihat korupsi terkikis habis dari bumi Indonesia.

TL: We are also continuing vigorously to execute the people's mandate of eradicating corruption. We carry out a systemic, sustainable, top down, and indiscriminate anti- corruption program. As the case in other countries, the fight against corruption in this country will always continue to face challenges and resistance. But we will never be discouraged, we will continue to try, because we all want to see it completely wiped out from the Indonesian soil.

First, we see the TL uses transposition in its translation where the word "anti corruption program" is located in the last of sentence. In addition, there is an expression on the SL, "tanpa pandang bulu" is translated in TL becomes "indiscriminate". It is verbal word "discriminate" add suffix "in" which means "not". Also, we find other suffix, "anti" which there is no change in its translation. It remains "anti" in TL. 
There is one way we can underline that semicolon (;) used in English language, Indonesian language seldom to use it. But, it is reverse, the semicolon we find in the SL, on the contrary the TL does not use it. Also, we find the expression in SL "korupsi terkikis habis dari bumi Indonesia". It describes that "corruption" is something which threatened for nation and country so that appears an expression to stress it which translated becomes "it completely wipe out from Indonesian soil". In addition, we can see the selected diction, "Indonesian soil" for "bumi Indonesia" used in TL.

SL: Hadirin sekalian yang berbahagia, Pekerjaan besar kita belum selesai. Masalah- masalah bangsa bukannya semakin berkurang, namun justru berkembang semakin kompleks. Di samping banyak capaian dan prestasi yang sangat membsarkan hati, Reformasi Gelombang Pertama juga banyak mengalami hambatan dan kekurangan, dan juga masih menyisakan sejumlah persoalan, yang disamping semuanya menjadi pelajaran yang berharga bagi kita semua, juga menjadi misi sejarah berikutnya.

TL: Ladies and Gentlemen, Our major work is not over yet. The nation's problems have not diminished, on the contrary, they have become more complex. Apart from the numerous very encouraging results and achievements, the First Wave of Reform has also a number of problems remain, not only they all serve as valuable lessons for of us, but they also become the subsequent historic mission.

From the text we see the diction "yang disamping semuanya menjadi pelajaran berharga" is translated becomes "not only they all serve as valuable lessons", The word in SL "menjadi" is translated becomes the diction "serve", it explain the formality for us. Also, from the text, it shows the tone such advice by saying the expression "as valuable lessons for of us" and "become the subsequent historic mission". Besides, we can see the formality by using diction "berikutnya" is translated becomes "subsequent". It does not use "the next" as its equivalent.

SL: Reformasi Gelombang Kedua mempunyai aspek ganda: perubahan dan kesinambungan - change and continuity. Tujuan Reformasi Gelombang Kedua bukan untuk mengubah haluan, namun untuk mempertegas haluan. Bukan untuk memperlambat, namun justru untuk memacu laju perubahan.

TL: The second Wave of Reform has a dual aspect: change and continuity. The goal of the Second Wave of Reform is not to alter the course, but to stress on its direction. Not to slow it down but, on the contrary, to spur the pace of change.

That sentence uses the ellipsis sentence "namun...untuk" is translated becomes "not...but". The diction also uses formal word so that makes the serious tone generally used in some speech. Also, we can see the diction to mark the formality from the text. The diction "mengubah haluan" translated becomes "alter the course". It does not use "change the course". Besides, we see the expression which gives a certain tone "to spur the pace of change".

SL: Kita masih harus mengawal dan membangun proses demokrasi dan desentralisasi yang begitu pesat perkembangannya, agar dapat menghadirkan pemerintahan yang 
bersih dan kapabel. Kita juga masih harus memberantas mafia hukum yang terus menggerogoti keadilan, dan menyengsarakan rakyat kita. Kita harus menuntaskan pekerjaan berat memberantas korupsi, yang nampaknya masih kita jumpai di berbagai jajaran pemerintahan, lembaga Negara dan dunia usaha.

TL: We still have to accompany and promote the fast- moving democratic and decentralization processes, in order to create a clean and able government. We must likewise continue to wipe out the law mafia which constantly undermines justice and subjected our people to sufferings. We have to finalize the hard work of eradicating corruption we can apparently still find in the rank and file of various government apparatuses, state institutions and the business circle.

That phrase uses the term of politics "mafia hukum" which means someone who buys and sell the law. It is negative connotation in political term. Also, the TL uses the expression "menggerogoti keadilan" translated "undermines justice". The diction "menggerogoti" means damage ploddingly, it sounds such euphemism.

SL: Jumlah penduduk yang semakin besar ini tentu membawa tantangan bagi kita untuk bekerja lebih keras dalam meningkatkan kesejahteraan rakyat, menciptakan kesempatan kerja, menghilangkan kemiskinan, meningkatkan pendidikan dan kesehatan, meningkatkan infrastruktur, dan memberikan pelayanan publik. Kita harus bekerja lebih keras lagi untuk mencapai sasaran Millenium Development Goals (MDGs) yang telah kita sepakati. Kedepan kita harus sungguh mengelola pertumbuhan penduduk kita. Program Keluarga Berencana untuk menciptakan keluarga sehat dan sejahtera harus benar- benar berhasil.

TL: Undoubtedly, such an increasingly big population constitutes challenge for us to work even harder, in order to improve the people's well- being, to create employment opportunities, to eradicate poverty, to promote education and health, to develop infrastructure and to provide public service. We have to work evenharder to reach the Millennium Development Goals that we have agreed upon. In the future, we must seriously manage our population growth. The Family Planning Program for creating a healthy and happy family must really succeed.

We can see the formality from the diction "...tentu" is translated becomes "undoubtedly". We generally say "surely or of course". Also, the diction "membawa tantangan" translated becomes "constitutes challenge". It does not say "bring or carry" for the equivalent. Besides, diction "meningkatkan kesejahteraan rakyat" is translated becomes "to improve the people's well being". It is no more says "prosperity" for its diction. The diction "untuk menghilangkan kemiskinan" is translated becomes "eradicate poverty". It used the same diction "eradicate" for corruption in the previous text. We also find the diction "untuk meningkatkan pendidikan dan kesehatan" is translated becomes "to promote education and health". The text uses the different diction to say "meningkatkan" in SL. The last sentence we find the acronym in SL "Program Keluarga Berencana $(\mathrm{KB})$ " is translated becomes "the Family Planning Program". 
We can conclude from the data which has been analyzed that the formality can be seen mostly from the diction. For a formal text, the diction or word order becomes important. They will give a stress by the diction which is used. Also, the formality appears in tone of the text. It explains how the text extend its aim is.

Furthermore, in the text we see some expressions that use a rhetoric style which is used by a President in his Speech. He uses it to give a tone to imply any essence for the public. Also, we can see some expressions which contains a lot of political terms. Those expressions give both positive and negative emotions that are finally to be such advice. From the text, it also appears some acronyms which are translated literally in target language. The acronyms consist of International and Regional terms, those include the institutional terms. Sometimes, they are translated becomes the initial or only in meaning.

The last, from the text we can see some expressions which show such euphemism. In addition, we see some borrowing words and the stranger suffix which derive from Greek. Also, there are some expressions such as connotation to describe a certain meaning or a situation. Those are the expressions which show the level of formality in President Speech.

\section{CONCLUSIONS}

The researcher can conclude that the text which was used is President Speech text. It contains the Source Language (SL) and the Target Language (TL). The writer compares the source language (Indonesia) and the target language (English) in President Speech. In analyzing, she uses the level of formality theory to analyze the expressions which are used in the text. The Level of Formality divided into five levels. They are Frozen, Formal, Consultative, Casual, and Intimate style. The President Speech text includes into Formal level. As a formal text, President Speech has to follow a certain regulation both in Source Language and Target Language, it is Standard English. Standard English involves some elements which have been standardized. They are grammar, diction, tone, style, etc. The text which is called as formal, if it has served those elements. Using Standard English has purpose to differentiate between Formal and Informal English. Formal and Informal English can be seen from their phonology, morphology, or syntax. In translation work, it is also important to be considered. We have to translate the Formal text by using Formal English; we may not translate it by using Informal English. On the other hand, if it is Informal text such as kids story, we also cannot translate it by using Formal English. From knowing the level of formality or register, the writer can analyze the language expressions on President Speech. The expressions which are analyzed can be seen from the unit of language such as from word, phrase, clause, or sentence. Finally, we can know why the President Speech is categorized as a Formal text. Also, knowing about what the aspects that show it different from the other level of formality are.

\section{BIBLIOGRAPHY}

Berk, Susan Seligson. The Bilingual Courtroom. Chicago: The University of Chicago

Press, 1990.

Chaedar, A. Walsilah. Sosiologi Bahasa. Bandung: Penerbit Angkasa, 1998. 
Halliday, M A K. Spoken and Written Language. Oxford: Oxford University Press, 1989.

Hatim, Basil, et al. Translation: An Advance Resource Book. Routledge, 2008.

Keraf, Gorys. Diksi dan Gaya Bahasa. Jakarta: Gramedia Pustaka Utama, 2007.

L, Richard Johanessen. Etika Komunikasi. Bandung: PT Remaja Rosdakarya, 1996.

Machali, Rochayah. Redefining Textual Equivalence in Translation. Jakarta: The Translation Centre, Faculty of Art- The University of Indonesia, 1998.

Nelson, W. Francis. The English Language: An Introduction Background For Writing.

New York: W. W. Norton\& Company. Inc, 1965.

Nurdin, Amin, et al. Menegerti Sosiologi: Pengantar Untuk Memahami Konsep-Konsep

Press, 2006.

Sosiologi. Ciputat: UIN Jakarta

Orwell, George. Language Awareness. New York: ST. Martin Press, 1974.

Sayogie, Frans. Teori dan Praktik Penerjemahan: Bahasa Inggris ke Dalam Bahasa Indonesia. Ciputat: Pustaka Anak Negeri, 2009.

Scharbach, Alexander. Critical Reading and Writing. San Fransisco: MacGrawHill, Inc, 1965.
Sugihastuti. Rona Bahasa dan Sastra Indonesia: Tangggapan Penutur dan Pembacanya. Yogyakarta: Pustaka Pelajar, 2009.

Wishnubroto, Widarso. Bahasa Inggris, Dialek, Ragam, Jargon, Slang, Blends, Clipped Words. Yogyakarta:

Kanisius, 1989. 
